\title{
Recreationist responses to livestock grazing in a new national monument
}

\author{
MARK W. BRUNSON AND LAEL GILBERT
}

Authors are Associate Professor, Dept. of Environment \& Society, Utah State University, Logan, Utah 84322-5215, and Media Manager, Institute for Outdoor Recreation \& Tourism, Utah State University, Logan, Utah. At the time of this research the junior author was graduate Research Assistant, Dept. of Forest Resources, Utah State University.

\begin{abstract}
Several U.S. rangeland areas recently have been designated as national monuments to protect scientifically or culturally important resources. Typically recreation and livestock uses have been retained in these areas. Because some people believe protection and use are incompatible, and because monument designation can increase public scrutiny of management while attracting new visitors to the area, we surveyed hunters and hikers in the Grand Staircase-Escalante National Monument, Utah, about their perceptions of livestock grazing in the monument. We examined associations between visitors' personal characteristics and their reports of how livestock grazing and multiple-use management affect recreation experiences. Recreation activity type was a significant predictor of experience effects, but we found no evidence that the act of designating a national monument itself affected experiences. Locations of current and childhood residence also were significantly associated with experience effects. Because designation tends to attract certain types of visitors more than others, creating rangeland national monuments may foster increased conflict between recreation and livestock grazing uses in those areas.
\end{abstract}

Public rangelands in the U.S. are managed for a wide range of social values, from commodities such as water and forage to less tangible services such as scenery, open space, and biodiversity (Hartmann et al. 1988, McClaran et al. 2001). Some highly vocal segments of society insist that environmental benefits to rare plants and animals, watersheds, and recreation opportunities must be enhanced by eliminating livestock grazing (Ferguson and Ferguson 1983, Wuerthner and Matteson 2002). In response, a political movement to protect traditional range uses, especially grazing, has emerged (Huffman 1994, Raymond 1997). These conflicting views have affected public land policymaking at the highest levels.

In 1996 the Grand Staircase-Escalante National Monument (GSENM) in southern Utah was designated to protect outstanding geology, paleontology, archeology, biology and history. Responding to competing political forces, President Clinton declared that the new monument would be of unprecedented size

This research was supported by the U.S. Department of Interior-Bureau of Land Management; the Institute for Outdoor Recreation and Tourism, Utah State University; and the Utah Agricultural Experiment Station, Logan, Utah 84322. Approved as UAES journal paper No. 7462.

Manuscript accepted 9 Jan. 03.

\section{Resumen}

Varias áreas de los pastizales naturales de los Estados Unidos han sido designados recientemente como monumentos nacionales para proteger recursos científicos o culturales importantes. Típicamente los usos para esparcimiento y pastoreo han sido retenidos en estas áreas. Debido a que alguna gente cree que la protección y el uso de los pastizales son incompatibles, y porque la designación de un monumento nacional puede aumentar el escrutinio público del manejo, atrayendo al mismo tiempo nuevos vistantes al área, encuestamos cazadores y excursionistas en el Grand Staircase-Escalante National Monument, Utah, sobre sus opiniones del pastoreo en el monumento. Examinamos la relación entre las características personales de los visitantes y sus informes sobre el efecto del pastoreo y el manejo de uso múltiple sobre sus experiencias recreativas. El tipo de actividad del esparcimiento fue un predictor significativo de las opiniones de la experiencia, pero no encontramos ninguna evidencia que el acto de designación de un monumento nacional sí mismo afectara las percepciones. Las localidades de la residencia actual y de la niñez también fueron asociadas significativamente con las percepciones. Debido a que la designación tiende a atraer ciertos tipos de visitantes más que a otros, la creación de los monumentos nacionales de pastizales puede fomentar conflicto creciente entre los usos para esparcimiento y para pastoreo en esas áreas.

for the lower 48 states, yet he also took the unusual step of proclaiming livestock grazing as a legitimate use (Clinton 1996). Although the proclamation does not mention recreation uses other than hunting, national monuments typically are managed for outdoor recreation, and parts of the GSENM have been popular recreation settings for many years. The Bureau of Land Management (BLM) retained management authority for the area, making it that agency's first national monument. Since the BLM manages for multiple use as mandated by the Federal Lands Policy and Management Act, GSENM managers needed to strike a balance between use and protection that potentially would differ from the agency's standard practices, but also from visitors' basic assumptions about the character of a national monument.

Before his term ended in January 2001, Clinton declared 14 more BLM national monuments, most of which face the same pressure to balance protective, recreational, and grazing management objectives. To find that balance, rangeland managers need information about the perceptions that recreation visitors have regarding other monument uses and values. It is important to know how different types of visitors respond to the presence of 
livestock, and moreover how designation of a national monument affects such responses. By understanding the characteristics of visitors who have antipathy toward grazing, managers are better equipped to address recreation/grazing conflicts. Alternatively, if recreationists report that their experiences are positively or neutrally affected by livestock grazing in some circumstances, managers can try to promote grazing primarily under those circumstances. Accordingly in 1999 we surveyed GSENM visitors about monument values, livestock grazing, and multiple-use management.

Grazing engenders strong feelings among rangeland stakeholders. In the literature of political advocacy, cows are often blamed for ecological and social problems on public lands. Opponents of public lands grazing say that cattle pollute scarce desert water sources, spread exotic plant species, expose soils to erosion, compete with wildlife for food, and damage archaeological and paleontological sites (Hedden 1999, Wuerthner and Matteson 2002). Involvement in outdoor recreation tends to be positively associated with measures of environmental concern (Dunlap and Heffernan 1975, Theodori et al. 1998), so we might expect an increase in recreation use caused by designation of the GSENM to lead to an increase in complaints about livestock use and impacts.

Studies of the link between outdoor recreation participation and environmental attitudes have not focused specifically on grazing, but there is limited evidence that perceptions of livestock use are associated with recreation activity style, classification of the land where grazing occurs, general environmental beliefs, and demographic characteristics. Sanderson et al. (1986) examined how national forest recreationists in Oregon reacted to grazing management practices. They measured ratings of scenic beauty in photographs that illustrated different levels of grazing management, and found these were significantly related to recreation activity. Fishermen rated most photographs less attractive than did hunters or campers, and seemed most sensitive to the relationship between livestock grazing and riparian areas; hunters rated photographs consistently higher than other groups. Breadth in recreation participation is positively related to support for grazing management (Sanderson et al. 1986, Brunson and Rasmussen 1995), i.e., the more variety there is in people's rangeland recreation repertoires, the less likely they are to judge grazing practices negatively. In particular, studies show that consump- tive recreationists such as hunters differ from non-consumptive users in some, though not all, aspects of environmental attitudes (Dunlap and Heffernan 1975, Donnelly and Vaske 1995, Theodori et al. 1998). Therefore we hypothesized that hikers and hunters would differ significantly in their perceptions of cattle grazing in the monument.

The location of encounters with grazing also affects visitor perception. Sanderson et al. (1986) found that frequent visitors to an area were more likely to accept intensive grazing management, but they also found that people who experienced close contact with cattle were more likely to express negative perceptions. Mitchell et al. (1996) found that visitors in dispersed campsites tended to be more critical of grazing than those in developed campgrounds, which are usually fenced off from livestock use. While there is little research to show that the act of land-use reclassification affects environmental perception, there is widespread popular belief in such a "designation effect" (Nash 1982, Power 1997). Land designations carry implications about the extent of influence on human activities: Hodgson and Thayer (1979) and Anderson (1981) found that lands with a protective designation (e.g., national park, wilderness) are evaluated differently than those with multiple-use designations. Johnson et al. (1997) found that respondents were more tolerant of grazing on non-wilderness public lands than on wilderness lands. These findings suggest that national monument designation could create a more idealized view of an area, especially among those who did not know it before designation. Those who had visited previously would be more likely to expect cattle (even though they might assume designation included a ban on grazing) and thus to tolerate their presence. Therefore, we hypothesized the pre- and post-designation users would differ significantly in their perceptions of grazing.

Research has shown that some sociodemographic characteristics are associated with judgments about nature and its management, including perceptions of grazing management. General environmental orientations have been found to vary with such personal attributes as age (Pierce et al. 1992), gender (Mohai 1992), education (Steel et al. 1990), rural/urban residence (Howell and Laska 1992), and economic dependence on natural resources (Brunson et al. 1997).

In a survey about federal rangelands and their management, Brunson and Steel (1996) found support for an urban/rural dichotomy in attitudes and beliefs, especially if the rural economy depends on rangelands. They also found that attitudes toward range management were driven by overall environmental attitudes. Sanderson et al. (1986) found that attitudes about range management varied by place of residence. Mitchell et al. (1996) found that the geographic location of a respondent's hometown was associated with perceptions of grazing, but the size of the community was not. We hypothesized that there would be significant associations between grazing perceptions and sociodemographic characteristics.

\section{Materials and Methods}

\section{Study area}

Sheep and cattle grazing has occurred in the Grand Staircase-Escalante region since Mormon pioneers settled the area in the spring of 1875 , drawn by the mild climate and relative abundance of grazing land (Powell 1994). The small towns of Escalante and Boulder remained frontier outposts for many years. Isolated from major highways and large cities, their growth was limited by what the natural resources could sustain. As access and facilities for travelers slowly improved, the area's sandstone canyons attracted increasing numbers of tourists to hike the Escalante River, view ancient indigenous rock art and structures, follow the historic Hole-in-the-Rock Trail, or drive scenic highways connecting the region with other national parks and monuments. The local economy today depends on tourism as much as on the natural resource mainstays of livestock and timber (Farmer 1999).

Designation of the area's public lands as a federally protected national monument afforded the area certain environmental protections as indicated under the Antiquities Act of 1906 and the presidential proclamation (Clinton 1996). Mining projects were shelved and limits were placed on some extractive uses. Despite these changes, federally leased grazing allotments were not immediately affected by the act of designation.

\section{Measures}

Our measurement instruments were surveys administered by mail. We designed separate questionnaires for hunters and backcountry visitors, but most survey items were identical and thus the responses can be compared. Surveys addressed several issues of interest to Grand Staircase-Escalante National Monument 
(GSENM) managers, including grazing perceptions. Specific variables used in the analysis described here include: frequency of sightings of cattle or evidence of cattle; qualitative evaluations of the vegetation condition and protected features; evaluations of whether livestock grazing or multiple-use management added to or detracted from recreation experiences; and personal characteristics of visitors.

Pre- and post-designation users were determined by means of a question asking when a respondent had first visited the monument. Visitors reporting 1996 or earlier were classified as "pre-designation." Visitation is highest in spring, and designation occurred in September 1996. Thus it is possible that respondents whose first visit was in 1996 already knew about designation, but that number is very small. Visitors who reported making their first visit in 1997 or later were classified as "post-designation." For this portion of the analysis only hikers were compared since the primary destination for hunters is not the monument but a particular hunting area.

\section{Sampling}

Hunters were contacted through a Fall 1999 hunter registration list maintained by the Utah Division of Wildlife Resources for its Paunsaugunt hunting unit, which is famous for its trophy mule deer hunting. Because only part of that unit falls within the GSENM, hunters were asked to fill out the survey only if they had hunted or scouted inside the monument. A map was provided to help hunters determine whether they had done so. Those who had hunted or scouted within the monument were asked to complete and return the survey; those who had not were asked to check a box on the cover and return the survey uncompleted.

No equivalent registration list exists for hikers. Backcountry hikers in a large, remote area such as the GSENM constitute a somewhat rare and elusive study population; to obtain the broadest possible sample, in March-September 1999 we assembled a list of visitor names and addresses from 3 sources: direct contacts by a researcher during GSENM visits, postcards placed on windshields of vehicles parked at trailheads, and participants in a voluntary backcountry permit system administered by the BLM.

On-site contacts occurred on trails and at trailheads. Although sampling times and sites covered the full range of hiking opportunities, we over-sampled on weekends and holidays, and at popular trails, to increase the chance of obtaining a statistically viable sample. Researchers approached all recreationists encountered during contact periods; if the visitor was engaged in backcountry hiking (i.e., non-motorized foot travel that entailed going one or more miles from one's vehicle), he or she was asked to participate in the survey and to supply a name and address for a subsequent mail questionnaire. When an unattended vehicle was seen at a trailhead, a postcard was placed on the windshield. The cards briefly described the survey and asked visitors to supply a name and address and return the card if their trip fit the criteria for backcountry use. All persons who returned a postcard received a questionnaire by mail.

Bureau of Land Management (BLM) employees supplied a list of addresses of persons who filled out voluntary permit forms available at the GSENM visitor center in Escalante and at many backcountry trailheads. Addresses of persons who already had been contacted in person were eliminated from this sample, and the remainder received mail questionnaires. Cover letters for this group differed slightly from those for the other 2 samples since the recipients had no previous knowledge that they would be receiving a survey, but the questionnaires themselves were identical.

Before combining hiker samples obtained in these different ways, it was necessary to compare responses across groups. Chi-square tests for comparison of frequency distributions were conducted for visitor attributes used in this analysis (sex, childhood residence, current state of residence, education), as well as the reported frequency of encounters with cattle or evidence of livestock use. No comparisons found statistically significant differences $(\alpha=.05)$, suggesting that all 3 sampling methods obtained members of the same population of backcountry hikers.

As a census of permit-holders, the hunter sample can be considered representative of the population of GSENM hunters. However, we cannot be as certain that the hiker sample was representative of the entire population of backcountry hikers in the GSENM. Because we over-sampled on days when visitor numbers were likely to be highest, persons who deliberately seek to avoid other visitors may be under-represented. Similarly, persons who prefer to minimize contact with managers might have been less likely to return windshield postcards or participate in a voluntary registration system. Previous research has shown that certain types of visitors may be less likely than others to use unat- tended trail registers; e.g., Lucas and Oltman (1971) found in a study of Oregon wilderness hikers that persons hiking alone, women, and people making comparatively shorter visits were less likely to sign trailhead registers.

Nonetheless, we are confident that we contacted the broadest possible cross-section of the GSENM hiker population given the constraints of the sampling situation, i.e., a relatively sparse, irregularly distributed population within a large $(>9,000$ $\mathrm{km}^{2}$ ) area. Moreover our response rates were very high for a lengthy, complex mail survey. Of 327 hikers who were contacted in person or by postcard, 277 completed and returned their surveys while 4 surveys were undeliverable, yielding a response rate of $86 \%$. For the 396 hikers sampled by voluntary permits, 32 surveys were undeliverable and 275 (76\% of deliverable surveys) were completed and returned. Hunter surveys were mailed to 327 people; 5 surveys were undeliverable and $216(67 \%)$ were either completed or returned by persons who did not hunt or scout in the GSENM. Because response rates were high, we did not attempt to contact non-respondents.

\section{Analysis}

Chi-square tests for differences in frequency distribution were used to assess whether perceptions of livestock grazing in the monument were associated with socio-demographic characteristics, recreation activity, or timing of first visit.

Due to inter-correlation among variables (e.g., hunters were overwhelmingly male, older people were more likely to have grown up in rural areas), polychotomous logistic regression estimates were obtained in order to isolate the associations between particular visitor characteristics and perceived impacts of management activities on recreation experiences. Polychotomous (or multinomial) logistic regression is a procedure that can be used to estimate the influence of non-continuous predictor variables on a categorical dependent variable (Bohrnstedt and Knoke 1994). This procedure produces separate logistic regression equations that predict $p_{i j}$, (i.e., the probability that the ith case is in the jth category of the dependent variable). N-1 models are obtained in this manner, where $\mathrm{N}$ is the number of baseline categories. In this analysis the dependent variables influence of livestock grazing and awareness of multiple-use on recreation experiences-contained 3 categories: "detracts from experience," "neutral," or "adds to experience." The latter was the omitted 
baseline category. With the exception of age, all characteristics were operationalized as dichotomous dummy variables; age was collapsed into 4 categories (under $25,25-40,41-55$, over 55).

\section{Results}

\section{Hunters and Hikers}

Hunters made up $22 \%$ of the total sample $(\mathrm{N}=155)$ and hikers $78 \%(\mathrm{~N}=552)$. Hunters were more likely than hikers to report having seen cattle or evidence of cattle (Table 1), though both groups reported seeing evidence of cattle frequently. Probably this is due to the locations where their activities take place. Most hikers visit the Escalante Canyons area where a number of grazing allotments have been retired since 1996, while hunting typically occurs in the western third of the monument where grazing is still the rule. When asked to attribute a cause for any vegetation impacts they encountered, both groups tended to mention cattle, but the tendency was greater among hunters than hikers ( $70 \%$ vs. $44 \%$ ). Hikers were more likely to ascribe impacts to human uses $(33 \%$ vs. $7 \%)\left(\chi^{2}=41.9, p=.013\right)$.

Respondents were asked if seeing cattle, or knowing that the area is open to multiple-use management, affected the quality of their recreation experiences (Table 2). Hunters were significantly less likely to report that seeing cattle detracted from their recreation experiences, and more likely to report that seeing cattle enhanced the experience. Similarly hunters were less likely to say that knowing the area is open to multiple-use management detracted from experiences and much more likely to say that it added to their experiences.

\section{Pre-Designation and Post- Designation Users}

Of 552 hiker respondents, $49 \%$ were classified as pre-designation visitors and $49 \%$ as post-designation; dates of first vis-

Table 1. Frequency of sightings by hunters and hikers of cattle or evidence of cattle in the Grand Staircase-Escalante National Monument (GSENM), 1999.

\begin{tabular}{lccccc}
\hline \hline $\begin{array}{l}\text { Impact type } \\
\text { Recreation group }\end{array}$ & Never & Rarely & Occasionally & Frequently & Chi-square $(p)^{1}$ \\
\hline $\begin{array}{l}\text { Cattle seen } \\
\quad \text { Hunters }(\mathrm{N}=155)\end{array}$ & 1 & 7 & 28 & 64 & $73.2(<.001)$ \\
$\quad$ Hikers $(\mathrm{N}=522)$ & 22 & 19 & 28 & 31 & \\
$\begin{array}{l}\text { Evidence seen } \\
\quad \text { Hunters }\end{array}$ & 1 & 7 & 26 & 66 & $10.7(.014)$ \\
$\quad$ Hikers & 7 & 11 & 27 & 55 & \\
\hline
\end{tabular}

The chi-square statistic here indicates probability that differences in frequency distributions of answers between hunters and hikers are attributable to random error.

Table 2. Reported effect of seeing cattle or knowing the area is open to multiple-use management on the quality of recreation experiences in the GSENM, 1999.

\begin{tabular}{lcccc}
\hline \hline $\begin{array}{l}\text { Impact Type } \\
\text { Recreation Group }\end{array}$ & $\begin{array}{c}\text { Detracts from } \\
\text { Experience }\end{array}$ & Neutral & $\begin{array}{c}\text { Adds to } \\
\text { Experience }\end{array}$ & Chi-square (p) \\
\hline $\begin{array}{l}\text { Seeing cattle } \\
\quad \text { Hunters }\end{array}$ & 39.1 & 35.8 & 25.2 & $56.3(<.001)$ \\
$\quad$ Hikers & 70.0 & 22.3 & 7.8 & \\
$\begin{array}{l}\text { Multiple-use } \\
\quad \text { Hunters }\end{array}$ & 2.6 & 14.6 & 82.8 & $97.8(<.001)$ \\
$\quad$ Hikers & 33.6 & 28.0 & 38.4 & \\
\hline
\end{tabular}

its were missing for the remaining respondents. Comparisons between pre- and post-designation visitors found no significant differences in frequency of cattle sightings, frequency of sighting evidence of cattle, judgments of vegetation impacts, judgments of impacts to other monument features, or the extent to which cattle grazing and multiple-use management influenced their recreation experiences positively or negatively.

\section{Demographic Characteristics}

Respondents were predominantly male ( $72 \%$ of hikers, $91 \%$ of hunters), with an average age of 37 in both groups. Hunters were more likely than hikers to live in Utah (87\% vs. $33 \%)$ and to have grown up in a small town or rural area instead of a city or suburb (68\% vs. $30 \%$ ). Median education levels were: high school diploma for hunters; Bachelor's degree for hikers.
Table 3 summarizes the relationships between 5 demographic characteristics and respondents' perceptions of the impact that livestock grazing and multiple-use management had on their monument recreation experiences. Each of the relationships listed was identified by means of a chi-square test for differences in frequency distribution $(\alpha=.05)$. We found no association between gender and influences of grazing and multiple-use management. Age was not associated with a perception of multiple-use management overall but was associated with perceptions of livestock grazing, as visitors age 65 and older were half as likely as younger visitors to say that seeing cattle strongly detracted from their visit. Utah residents, persons who grew up in a small town or rural area, and persons with lower levels of educational attainment were less likely to say that seeing livestock grazing or

Table 3. Summary of relationships between demographic characteristics and influences of livestock grazing and multiple use management on recreation experiences, GSENM, 1999.

\begin{tabular}{|c|c|c|c|c|c|}
\hline Potential influence & Utah resident? & Age & Gender & Residence & $\begin{array}{l}\text { Childhood } \\
\text { Education }\end{array}$ \\
\hline Livestock Grazing & $\begin{array}{l}\text { Utahns less likely } \\
\text { to say "detracted"* }\end{array}$ & $\begin{array}{l}\text { Older residents } \\
\text { less likely to } \\
\text { say "detracted" }\end{array}$ & NS & $\begin{array}{l}\text { Rural residents } \\
\text { less likely to } \\
\text { say "detracted" }\end{array}$ & $\begin{array}{l}\text { Less-educated } \\
\text { less likely to } \\
\text { say "detracted" }\end{array}$ \\
\hline $\begin{array}{l}\text { Multiple-use } \\
\text { Activities }\end{array}$ & $\begin{array}{l}\text { Utahns less likely } \\
\text { to say "detracted }\end{array}$ & NS & NS & $\begin{array}{l}\text { Rural residents } \\
\text { less likely to } \\
\text { say "detracted" }\end{array}$ & $\begin{array}{l}\text { Less-educated } \\
\text { less likely to } \\
\text { say "detracted" }\end{array}$ \\
\hline
\end{tabular}

$* \chi^{2}$ test for difference in frequency distribution, $\mathrm{P}<.05$ 
Table 4. Parameter estimates for polychotomous logistic regression of the reported effect upon recreation experiences of seeing livestock grazing (omitted category: persons for whom grazing added to the experience), GSENM, 1999.

\begin{tabular}{lccc}
\hline \hline & $\begin{array}{c}\text { Logistic } \\
\text { Coefficient }\end{array}$ & $\begin{array}{c}\text { Standard } \\
\text { Error }\end{array}$ & T ratio \\
\hline Dariable & & & \\
Detracted from experience $(N=395):$ & .51 & .42 & 1.22 \\
Constant & .69 & .34 & $2.04^{*}$ \\
State $(1=$ Utah, $0=$ other $)$ & -.63 & .33 & -1.88 \\
Sex $(1=$ Male, $0=$ female $)$ & .08 & .30 & -0.26 \\
Pre/post designation $(1=$ pre, $0=$ post $)$ & -.08 & .30 & $3.17^{* *}$ \\
Childhood locale $(1=$ rural, $0=$ urban $)$ & .84 & .33 & -0.45 \\
Education $(1=$ college, $0=$ high school) $)$ & .15 & .50 & $-3.35^{* *}$ \\
Activity type $(1=$ hiker, $0=$ hunter $)$ & -1.23 & .38 & 1.63 \\
Age under 25 & .81 & .39 & $3.05^{* *}$ \\
Age 26-40 & 1.15 & & $4.01^{* *}$ \\
Age 41-55 & 1.57 & .46 & \\
Did not affect experience $(N=162)$ & & .36 & -0.44 \\
Intercept & -.20 & .36 & 1.20 \\
State $(1=$ Utah, $0=$ other $)$ & .43 & .31 & -1.61 \\
Sex $(1=$ Male, $0=$ female $)$ & -.57 & .31 & 0.95 \\
Pre/post designation $(1=$ pre, $0=$ post $)$ & .30 & .35 & 1.65 \\
Childhood locale $(1=$ rural, $0=$ urban) & .52 & .39 & 0.33 \\
Education $(1=$ college, $0=$ high school $)$ & 15 & .45 & -1.18 \\
Activity type $(1=$ hiker, $0=$ hunter $)$ & -.48 & .40 & 0.90 \\
Age under 25 & .48 & .42 & 1.86 \\
Age 26-40 & .75 & $3.09^{*}$ \\
Age 41-55 & 1.28 & & \\
\hline
\end{tabular}

knowing the area is open to multiple-use activities detracted from their visits to the monument.

Before concluding that perceptions are associated with demographic characteristics, we considered an alternate hypothesis that the differences in recreation experience perceptions were a function of differences in the extent to which persons in various demographic categories encountered evidence of grazing and multipleuse. Therefore we measured correlations between reported encounters and demographic characteristics. We found only 1 such correlation: older visitors were slightly less likely to report seeing evidence of livestock (perhaps because they travel fewer miles on foot). Therefore we interpret the findings as evidence that acceptability of grazing and multiple-use management is associated with demographic factors.

\section{All Visitor Characteristics}

Analysis of the relationship between demographic characteristics and the effect of livestock grazing on recreation experience (Table 4) shows that the effect of livestock grazing on recreation experience is dependent upon current state of residence, rural/urban nature of one's childhood residence, type of recreation activity, and age. Visitors are more likely to say grazing detracted from the experience if they are from outside Utah, grew up in an urban area, hiked, or are between the ages

$* \mathrm{P}<.05 \quad * * \mathrm{P}<.01$

of knowing the area is open to multipleuse activities on recreation experience (Table 5) shows that experience perceptions are associated with state of current residence, location of childhood residence, education, and activity type. Visitors are more likely to say their experience was negatively affected by knowing the area is open to multiple-use if they are from out of state, grew up in an urban area, graduated from college, or hiked. They were more likely to say there was no effect (rather than to say it added to the experience) if they were from out-of-state, grew up in an urban area, or hiked.

\section{Discussion}

We hypothesized that there would be significant differences between hunter and hiker perceptions of livestock grazing. This hypothesis was supported. Hunters saw cattle and evidence of cattle more often than hikers, partly because hiking tends to take place in areas where less livestock grazing takes place, and perhaps also because hunters venture off trails and away from canyons more than hikers. They were less likely to say that livestock grazing detracted from their experiences; however, those hunters who reported moderate or heavy vegetation impacts were more likely than hikers to attribute those impacts to cattle. It may seem counterintu-

Analysis of the relationship between demographic characteristics and the effect

of 26 and 55 . The only variable that influences whether grazing had no effect is age: 41- to 55-year olds are more likely than other age groups to say there was no effect, and less likely to say grazing added to the experience.

Table 5. Parameter estimates for polychotomous logistic regression of the reported effect upon recreation experiences of knowing the area is open to multiple use (omitted category: persons for whom knowing about multiple-use added to the experience), GSENM, 1999.

\begin{tabular}{|c|c|c|c|}
\hline Variable & $\begin{array}{c}\text { Logistic } \\
\text { Coefficient }\end{array}$ & $\begin{array}{c}\text { Standard } \\
\text { Error }\end{array}$ & $\mathrm{T}$ ratio \\
\hline \multicolumn{4}{|l|}{ Detracted from experience $(N=173)$ : } \\
\hline Intercept & -.84 & .37 & $-2.28 *$ \\
\hline State $(1=$ Utah, $0=$ other $)$ & .77 & .25 & $3.14^{*}$ \\
\hline $\operatorname{Sex}(1=$ Male, $0=$ female $)$ & -.27 & .25 & -1.09 \\
\hline Pre/post designation $(1=$ pre, $0=$ post $)$ & -.37 & .23 & -1.61 \\
\hline Childhood locale $(1=$ rural, $0=$ urban $)$ & .5 & .23 & $2.45^{*}$ \\
\hline Education $(1=$ college, $0=$ high school $)$ & -.90 & .30 & $-2.95 * *$ \\
\hline Activity type $(1=$ hiker, $0=$ hunter $)$ & -2.44 & .54 & $-4.45^{* *}$ \\
\hline Age under 25 & .67 & .45 & 1.48 \\
\hline Age $26-40$ & .54 & .33 & 1.63 \\
\hline Age 41-55 & .01 & .32 & 0.15 \\
\hline \multicolumn{4}{|l|}{ No effect on experience: $(N=164)$} \\
\hline Intercept & -1.15 & .37 & $-3.15 * *$ \\
\hline State $(1=$ Utah, $0=$ other $)$ & .53 & .24 & $2.21^{*}$ \\
\hline $\operatorname{Sex}(1=$ Male, $0=$ female $)$ & .00 & .24 & 0.01 \\
\hline Pre/post designation $(1=$ pre, $0=$ post $)$ & -.01 & .22 & -0.05 \\
\hline Childhood locale $(1=$ rural, $0=$ urban $)$ & .50 & .22 & $2.27^{*}$ \\
\hline Education $(1=$ college, $0=$ high school $)$ & -.41 & .25 & -1.64 \\
\hline Activity type $(1=$ hiker, $0=$ hunter $)$ & -.66 & .30 & $-2.17 *$ \\
\hline Age under 25 & .54 & .43 & 1.30 \\
\hline Age $26-40$ & .39 & .33 & 1.18 \\
\hline Age $41-55$ & .25 & .31 & 0.80 \\
\hline
\end{tabular}


itive that hunters were more likely to attribute impacts to cattle while less likely to mind seeing them, but this may be a reflection of demographics: Hunters were more likely to have a rural childhood and to be from Utah, and therefore may be more used to seeing and identifying impacts, but also more tolerant of cattle and their effects on vegetation. More than half of all hunters said knowing the area is open to multiple uses "strongly added" to their experiences. To some extent this is probably a political statement: Since national monuments have usually been managed as protected areas where hunting is not an allowed use, hunters may simply be indicating that multiple-use management means they are less likely to be barred from their preferred activity within the GSENM.

Based on the findings of Hodgson and Thayer (1979) and Anderson (1981), who found that protective designations affect how people think about natural places, we also hypothesized that there would be significant differences in perceptions of persons who had visited the area prior to designation versus those who knew it only as a national monument. This hypothesis was not supported. Opponents of protectedarea designation sometimes argue that such designations make it harder to achieve management objectives even if management options remain ostensibly flexible (e.g., Heidemann 2001). And since growth in protected-area tourism often brings an increase in undesirable environmental impacts (Wang and Miko 1997), it is sometimes argued that protection is actually counter-productive. In this study we were not able to measure changes in conditions as a result of designation, but we were able to compare perceptions of hikers whose ideas about the GSENM were likely to have been formed prior to designation with perceptions of those whose ideas were likely to have been formed subsequent to designation. We found no differences between these 2 groups. This may indicate that the concern about a "designation effect" is overemphasized, or it may simply reflect a situation where pre-designation users were already unhappy about grazing and interactions with livestock.

Finally, we hypothesized that demographic characteristics would be significant predictors of grazing perceptions. This hypothesis was partially supported. Even after controlling for activity, respondents' current and childhood residences and age were associated with negative perceptions of grazing livestock. Education and current and childhood residence were associated with perceptions of multipleuse management irrespective of activity. However, education and age effects were not as strongly associated as other characteristics, and gender was not found to be a predictor of perceptions of either grazing or multiple-use management.

\section{Conclusion and Implications}

The question raised at the start of this paper was: Will the designation of rangeland national monuments restrict managers' ability to use livestock grazing and other multiple-use management strategies, even if such management remains legal under terms of the national monument proclamation. Based on this study, we have to answer "yes and no." We did not find evidence that the mere fact of designation affects the perception visitors have regarding a rangeland protected area. However, we did find differences between visitors seeking different types of recreation experiences, as well as differences rooted in the demographic characteristics of visitors. And it's likely that designation will attract more of the types of visitors who are least likely to support traditional range management activities.

Hikers were more likely than hunters in our study to feel negatively toward livestock and multiple-use management. Designation of the Grand StaircaseEscalante National Monument (GSENM) did attract new visitors - nearly twice as many in 1997 as in 1996 (Stauffer 1999). While highway tourists made up the majority of the new visitors, hiking has also increased. Meanwhile, growth in hunting is restricted because of limitedaccess management intended to maintain a trophy mule-deer hunting experience. Even if hunter access to other rangeland national monuments is not restricted, hiking growth is likely to be greater simply because many more people hike than hunt in the U.S. (Hartmann et al. 1988).

Moreover, designation appears to have brought visitors to the monument from greater distances. Comparing our survey results with those of a study in 1996 just prior to designation (Ruehrwein 1998), we found that hikers in 1999 were younger, and twice as likely to be from a state other than Utah. Since older visitors and Utah residents were significantly less likely to view livestock grazing negatively, designation appears to have increased the likelihood that visitors will be affected negatively by grazing use. Although our sam- ple was not large enough to measure variation in responses by residents of different states, prior studies (e.g., Brunson and Steel 1996, Reiter et al 1999) have shown that persons from outside the Intermountain West feel more negatively toward traditional approaches to range management. If designation of a national monument draws more visitors from outside the immediate region of the monument - as appears to be the case with the GSENM - then one consequence is likely to be an increase in levels of conflict between recreation uses and livestock grazing. As managers of the new BLM monuments finish developing management plans, they would be well advised to develop strategies - e.g., retiring allotments or adjusting grazing seasons in areas of the monument that receive the heaviest visitor use - that can mitigate such conflicts as they arise.

\section{Literature Cited}

Anderson, L.M. 1981. Land use designation affect perceptions of scenic beauty in forest landscapes. Forest Sci. 27:392-400.

Bohrnstedt, G.W. and D. Knoke. 1994. Statistics for social data analysis. F.E. Peacock, Itasca, Ill.

Brunson, M.W. and G.A. Rasmussen. 1995. Rangeland recreation use and attitudes toward range management. Abstract $48^{\text {th }}$ Annual Meeting, Soc. for Range Manage., Phoenix, Ariz.

Brunson, M.W. and B.S. Steel. 1996. Sources of variation in attitude and beliefs about federal rangeland management. J. Range Manage. 49:69-75.

Brunson, M.W., B. Shindler, and B.S. Steel. 1997. Consensus and dissention among rural and urban publics concerning forest management in the Pacific Northwest. Ch. 6 in B.S. Steel, ed., Public Lands Management in the West: Citizens, Interest Groups, and Values. Praeger, Westport, Conn.

Clinton, W.J. 1996. Establishment of the Grand Staircase-Escalante National Monument by the President of the United States of America: a proclamation. Presidential Proclamation 6920. September 18,1996

Donnelly, M.P. and J.J. Vaske. 1995. Predicted attitudes toward a proposed moose hunt. Soc. and Natural Resour. 8:307-319.

Dunlap, R.E. and R.B. Heffernan. 1975. Outdoor recreation and environmental concern: an empirical examination. Rural Sociol. 40:18-30.

Farmer, J. 1999. Glen Canyon Dammed: Inventing Lake Powell and the Canyon Country. Univ. of Arizona Press, Tucson, Ariz.

Ferguson, D. and N. Ferguson. 1983. Sacred Cows at the Public Trough. Maverick Publ., Bend, Ore. 
Hartmann, L.A., H.K. Cordell, and H.R. Freilich. 1988. The changing future of outdoor recreation activities. Trends 25(4):19-23.

Hedden, B. 1999. Escalante grazing retirement. Colorado Plateau Advocate (Summer 1999):1-3.

Heidemann, C. 2001. Multiple use policies in the Grand Staircase-Escalante National Monument: Is Clinton's promise legitimate or mere political rhetoric? BYU J. Publ. Law 16:37-68.

Hodgson, R.W. and R.L. Thayer Jr. 1979. Implied human influence reduces landscape beauty. Landsc. Plann. 7:171-179.

Howell, S. and S. Laska. 1992. The changing face of the environmental coalition: a research note. Envir. \& Behavior 24:134-144.

Huffman, J.L. 1994. The inevitability of private rights in public lands. Public Lands and Resour. Law Digest 31:327-363.

Johnson, L.C., G.N. Wallace, and J.E. Mitchell. 1997. Visitor perceptions of livestock grazing in five U.S. wilderness areas. Intl. J. Wilderness 3:14-20.

Lucas, R.C. and J.L. Oltman. 1971. Survey sampling wilderness visitors. J. Leisure Res. 3:28-43.

McClaran, M.P., M.W. Brunson, and L. Huntsinger. 2001. Future social changes and the rangeland manager. Rangelands 23(6):33-35.
Mitchell, J.E., G.N. Wallace, and M.D. Wells. 1996. Visitor perceptions about cattle grazing on National Forest land. J. Range Manage. 49:81-86.

Mohai, P. 1992. Men, women, and the environment: an examination of the gender gap in environmental concern and activism. Soc. \& Natur. Resour. 5:1-19.

Nash, R. 1982. Wilderness and the American Mind. Yale University Press, New London, Conn.

Pierce, J.C., M.A. Steger, B.S. Steel and N.P. Lovrich. 1992. Citizens, Political Communication, and Interest Groups: A Study of Environmental Organizations in Canada and the United States. Praeger, Westport, Conn.

Powell, A.K. (Editor). 1994. Utah History Encyclopedia. University of Utah Press, Salt Lake City, Utah.

Power, T.M. 1997. Eco-amenities in the Pacific Northwest: Is environmental regulation a tool for economic growth? PERC Reports 15(1):3-4.

Raymond, L. 1997. Viewpoint: Are grazing rights on public lands a form of private property? J. Range Manage. 50:431-438.

Reiter, D.K., M.W. Brunson, and R.H. Schmidt. 1999. Public attitudes toward wildlife damage management and policy. Wildl. Soc. Bull. 27:746-758.
Ruehrwein, R.J. 1998. Exploring Knowledge, Attitudes and Reported Behaviors of Southern Utah Backcountry Recreationists. M.S. thesis, Utah State University, Logan, Utah

Sanderson, R.H., R.A. Meganck, and K.C. Gibbs. 1986. Range management and scenic beauty as perceived by dispersed recreationists. J. Range Manage. 39:464-469.

Stauffer, C.J. 1999. A Qualitative Look at Backcountry Recreation in the Grand Staircase-Escalante National Monument. M.S. thesis, Utah State Univ., Logan, Utah

Steel, B.S., D. Soden, and R. Warner. 1990. The impact of knowledge and values on perceptions of environmental risk to the Great Lakes. Soc. \& Natur. Resour. 3:331-348.

Theodori, G.L., A.E. Luloff, and F.K. Willits. 1998. The association of outdoor recreation and environmental concern: reexamining the Dunlap-Heffernan thesis. Rural Sociol. 63:94-108.

Wang, C.Y. and P.S. Miko. 1997. Environmental impacts of tourism in U.S. national parks. J. Travel Res. 35(4):31-36.

Wuerthner, G. and M. Matteson, eds. 2002. Welfare Ranching: The Subsidized Destruction of the American West. Island Press, Washington, DC. 